\title{
Financial Modeling for Modular and Offsite Construction
}

\author{
Tarek Salama, Gareth Figgess, Mohamed Elsharawy, Hossam El-Sokkary
}

\begin{abstract}
The advantages of using modular and offsite construction compared with the traditional construction methods are numerous due to its efficiency in delivering shorter schedules, lower cost, higher quality, and better safety. However, one of the biggest challenges facing the prefabrication industry today is the inherent difference between financing traditional construction and the upfront capital requirements for modular and offsite construction. Any solution for this problem should introduce better coordination among developers, banks, financial partners, lending institutions, manufacturers, and general contractors. Financing modular construction is challenging as banks are not familiar with the characteristics of this modern industry, and it is all about risk and return. Financing also helps in reducing risk for developers and allows them to undertake projects without having the upfront capital. However, few studies in literature focused on the financial modeling for modular and offsite construction. This paper is presenting a state-of-the art literature review for current practices concerning financial modeling for modular and offsite construction. This review discusses current challenges for financing this industry, as well as the introduced initiatives by governments to facilitate financing of modular and offsite construction. Conclusions are presented regarding the current practices for funding the prefabrication industry. Furthermore, recommendations are drawn for encouraging the development of prefabricated housing, and its ability in solving the current shortage of housing in different parts of the world.
\end{abstract}

Keywords: Instructions, Financial Modeling, Modular, Offsite Construction, Literature Review.

\section{INTRODUCTION}

Shortage of affordable housing for low-income renters is affecting every state and metropolitan area in America. The private market is not producing enough affordable new rental housing to these renters, because rents they can afford do not typically cover development and operating costs for rental housing [1], while public supporting subsidy is absent on this regard. Mayors of Philadelphia, New York and San Francisco confirmed that modular construction is a solution to the

Revised Manuscript Received on December 25, 2020.

* Correspondence Author

Tarek Salama, Department of Construction Engineering, California State University, Sacramento, California, USA. E-mail: salama@csus.edu

Gareth Figgess, Department of Construction Engineering, California State University, Sacramento, California, USA. E-mail: figgess@csus.edu

Mohamed Elsharawy*, Structural Engineering Department, Mansoura University, Mansoura, Egypt. E-mail: m_sharawy@mans.edu.eg

Hossam El-Sokkary, Structural Engineering Department, Ain Shams University, Cairo, Egypt. E-mail: elsokkary.hossam@eng.asu.edu.eg

(c) The Authors. Published by Blue Eyes Intelligence Engineering and Sciences Publication (BEIESP). This is an open access article under the CC BY-NC-ND license (http://creativecommons.org/licenses/by-nc-nd/4.0/) housing problem in their cities [2] due to its reported advantages. However, many studies investigated barriers of modular construction to increase its market share [3]-[8]. These barriers include 1) modular and offsite construction's negative stigma; 2) lack of evidence for successful application of modular and offsite construction; 3) lack of unified building codes and operational standards for modular and offsite construction; 4) traditional procurement systems do not fit practices of modular and offsite construction; 5) conventional financing tools and cash flow structures does not enable the use of modular construction. Rahman [3], Smith and Rice [4] listed the difficulty in financing, as one of the main barriers to implement offsite construction, because it requires higher initial capital compared to traditional approach. The Canadian construction innovations report [5] highlighted, cash flow challenges for modular and offsite construction when using the traditional cash flow system and outlined the need to restructure project financing for publicly funded projects to enable the application of modular construction. Salama et al. [6]-[8] emphasized the need to generate financial models to fit the characteristics of modular construction and to hold conferences or symposiums for lenders to discuss the different nature of financing modular and offsite construction. The same studies also suggested to create special lending banks and changing policies for financing modular builders as well as convincing insurance companies to lower insurance rates for modular buildings. Furthermore, they also recommended universities to design cost management methods and lending programs that consider characteristics of modular construction. This paper presents a literature review for current practices in financing modular and offsite construction and discusses different initiatives that encourage financing modular builders.

\section{CHALLENGES}

\section{A. Large upfront capital requirements}

The production and procurement processes for modular construction require material and overhead costs to equal up to 60 percent of a module's total cost. Hence, manufacturers ask for an upfront payment of around 50 percent at the ordering time to procure materials in short period of time to increase efficiency of manufacturing [9]. This large upfront capital requirements from manufacturers can affect bank reserves, so banks and institutional lenders would ask for any collateral to reserve some money on their equity to avoid scrutiny from regulators [10].

\section{Published By:}

Blue Eyes Intelligence Engineering and Sciences Publication

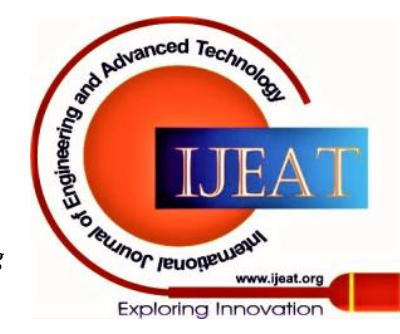




\section{Financial Modeling for Modular and Offsite Construction}

\section{B. Perception of ownership}

During manufacturing, modules are considered personal property of the manufacturer and it does not become real private property until delivery and assembly onsite [10]. Many banks do not release financing instalments until modules are installed onsite to ensure that their money is utilized in real property.

However, manufacturers want to get paid before delivery of modules to avoid the transfer of ownership status from personal to private property which can lead to legal complication to future payment disputes [11]. These differences in understanding for perception of ownership of modules complicate financing instalments and the whole financing structure.

\section{The immature market}

Modular construction developers who lack the experience in this industry, face uncertainty in scheduling and pricing which results in risks' inconsistencies. Banks' evaluations for their projects can change and financing costs would increase for developers [12]. Banks are also concerned regarding project completion if a manufacturer becomes bankrupt. Few American companies can manage high-rise modular projects, and lack of proven manufacturing would make banks request additional contingency funds to satisfy projects' uncertainty [13]. Immature market affect pricing of manufacturers and it would make it unreliable.

\section{Progress monitoring for manufacturing}

Progress monitoring for manufacturing is hard for modules that can be manufactured simultaneously for multiple projects. Materials allocation is crucial for identifying a collateral to get financing from any bank. Securing financing for modular construction can be more difficult than traditional projects because banks would not prefer the increased risk associated with progress monitoring of manufactured modules [12].

\section{E. Lack of support from authorities and financial sector}

Lack of support from financial sector is a main challenge for offsite construction due to many reasons like the high profitability of lenders who finance traditional housing [14]. Many offsite manufacturers have to internally finance their projects until the end of manufacturing. Hence, only the most successful builders can manage large-scale projects with reasonable cost. Production of modules can begin six months before delivery of first module on site based on size of different projects, while procurement of materials should start 6-7 weeks before manufacturing [15]. This means modular manufacturer has to pay for materials and then pay for labor during manufacturing of modules while banks release construction financing after delivery of modules to construction site. Depending on project size, modular manufacturer may need \$16-\$20 million before receiving any financing from lenders [15]. Lack of political will from regulatory authorities to motivate lenders to change their policies is also questionable [14].

\section{F. High lending rates}

Lending rates for offsite construction are higher than its value for traditional construction because it is relatively a new concept and many banks lack the full understanding of it [16]. However, these rates will be changed by time after more research and development initiatives are undertaken, and higher scale of this market is achieved. For example, a two-year traditional construction project can make the developer pay half of the cost up front for the land and the other half is paid throughout the two years of construction. However, for modular construction project with a compressed project time of one year, the whole payment can be due upfront, while financing could be required for only one year instead of two years. If cost of capital is assumed to be 10 percent, then financing costs would be reduced by 5 percent of the total project cost [16].

\section{G. Financial impact and considerations}

The potential financial impact from utilizing modular and offsite construction should be investigated and compared to stick-built construction before project can start. Financial impact is different from a state and country to another and many factors should be studied to assess financial impact such as the high labor cost in some countries. Economic situation for housing market, debt situation, and developer capabilities also affect the financial impact which must be evaluated before taking a decision to utilize offsite construction [11].

\section{H. Transportation and storage costs}

Transportation and storage costs are essential for modular and off-site construction. However, lending banks may not consider them while providing construction financing [17]. Additional costs may also face developers such as renting trailers for transportation and wrapping prefabricated modules to protect them from weathering effects and possible damages. These costs are challenging if project site and manufacturing facility exist in different countries.

\section{Payment certifications for publicly funded projects}

If a modular or offsite construction project is publicly funded, then its schedule of values may not fit with a typical schedule of values developed by the American institute of architects (AIA), which determines monthly progress payments. Some publicly funded projects may not permit some payments certifications in a timely manner due to this challenging fact [18].

\section{MODULAR AND OFFSITE CONSTRUCTION TEAM}

For traditional, modular and offsite construction, clients are developers or building owners, who may be individuals, groups, or representatives for owners. They are motivating building projects by providing funding and determining the required delivery method, as well as construction method utilized, whether prefabricated or not, and the level of required prefabrication with the help of the design team [19]. Relationship between developer and project team for traditional construction is shown in Figure 1 where developer may have contracts with different designers and consultants (e.g., Architect, structural, and civil consultants),

Published By:

Blue Eyes Intelligence Engineering

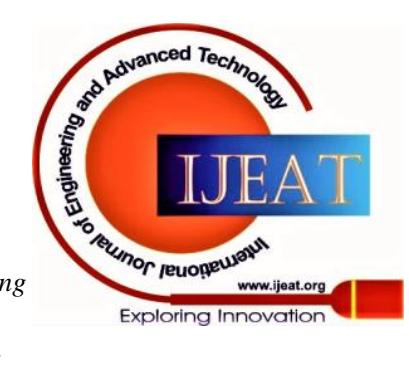


and another contract with the general contractor who may hire different subcontractors. For modular and offsite construction, the developer may have a contract with the modular builder as shown in Figure 2 who can manage fabrication and may or may not hire a general contractor to establish building foundation and utilities onsite.

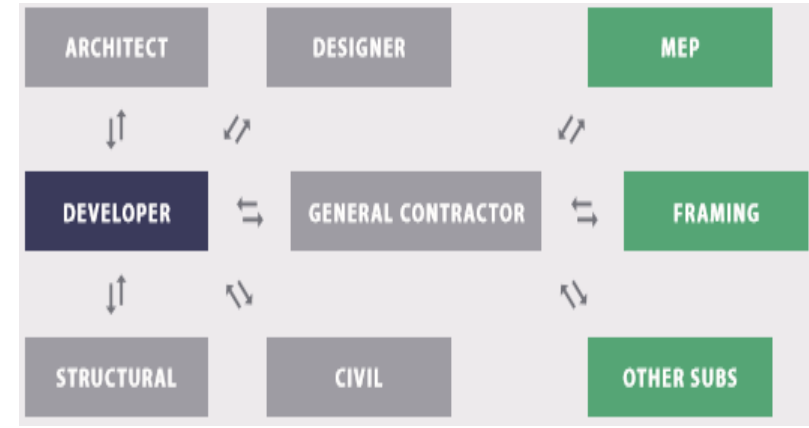

Fig. 1. Traditional construction team (Adapted from MBI report [1])

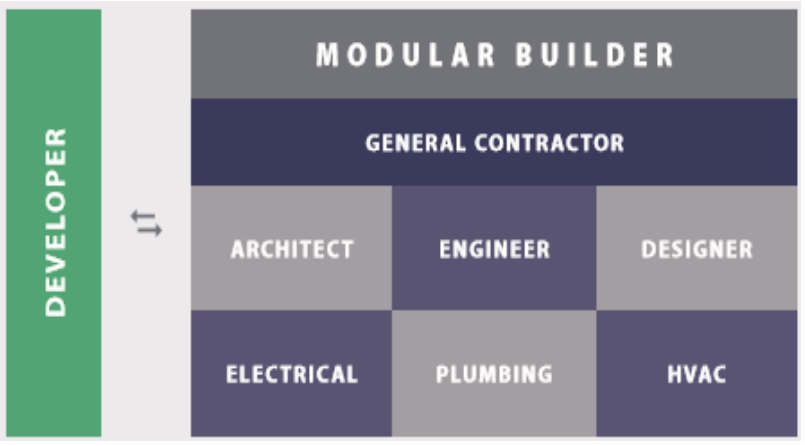

Fig. 2. Modular construction team (Adapted from MBI report [1])

\section{FINANCIAL MODELING}

\section{A. Financial modeling from developer perspective}

Few studies investigated insights of financing offsite construction from developer perspective $[11,20]$. Cameron and Carlo [11] conducted a quantitative analysis to assess the impact of utilizing modular construction. Two scenarios were used to measure equity internal rate of return (IRR) - which is the annualized return of investment in any period of time - in a comparison between modular and traditional construction. The first scenario is for a project comprising six buildings constructed as rent development, while the second is for the same project assuming it is constructed for sale. It was concluded that equity IRR increased when utilizing modular construction compared to traditional construction from $35.1 \%$ to $47.5 \%$ for the first scenario, and from $25.75 \%$ to $27.60 \%$ for the second scenario. Difference between equity IRR of first and second scenarios is attributed to the earned rental income for part of the development. Difference between equity IRR of modular and traditional construction is attributed to flexible phasing of modular construction since for example, two buildings can be installed onsite to be ready for rental or sale while another building is being manufactured offsite. Shorter schedules of modular construction allow modular developers to reduce interest payments due to the shorter loan period and they can make additional cost savings due to shortened schedules that would reduce the general conditions cost and risk insurance. Cazemier [20] conducted a comparative financial analysis between a cross laminated timber (CLT) building that utilizes offsite construction technologies, and traditional concrete and steel building in Australia to study economic benefits of using CLT. Feasibility model variables such as sales revenue, land purchase price, construction cost, construction contingency, professional fees, and interest expenses were inputted into EstateMaster software to model their effects on key performance indicators such as development margin, development profit, Return on Equity (ROE) - which is the total amount of return receive on original investment - , and IRR. It was concluded that buildings constructed with CLT may result in less development margin, development profit, and ROE, however it will increase equity IRR due to the reduced investment timeline for offsite construction which is the same conclusion of Cameron and Carlo [11]. It was also outlined that any developer will choose between using CLT or traditional buildings based on their investment requirements whether they prefer a greater total amount of return for shareholders on their original investment by the increased $\mathrm{ROE}$, or receive higher annual return of investment by the increase of equity IRR [20]. However, this study is based on using CLT in the Australian market, hence other types of offsite construction such as modular or hybrid construction in other markets like USA or UK might result in different values of ROE and IRR due to the different interest rates, land purchase price, and construction costs in both countries.

\section{B. Mortgage financing for consumers}

Manufactured housing percentage is nearly $6 \%$ of occupied housing and accounts for much smaller percentage of home loans in the U.S. [21]. Manufactured homes are commonly used in Western and Southern states as shown in Figure 3 [21], and two-thirds of manufactured homes are outside of metropolitan areas in the U.S. Residents of manufactured homes tend to be older and they have lower net worth and incomes compared to residents of traditional homes and they also pay higher loan interest rates than borrowers for traditional homes [21]. Loans for $68 \%$ of manufactured homes are considered "higher-priced mortgage loan" (HPML), which is a definition for loans considered to have high subprime. While only $3 \%$ of loans for traditional construction are considered HPMLs [20]. De Mendoza [22] presented a comparison between financial mechanisms for offsite construction in New Zealand and different countries such as USA, Japan, Australia, and Sweden. The main aim of this study is to introduce financial initiatives to encourage offsite construction since New Zealand lacks such financial initiatives where banks do not issue mortgages for manufactured housing.

\section{Published By:}

Blue Eyes Intelligence Engineering and Sciences Publication

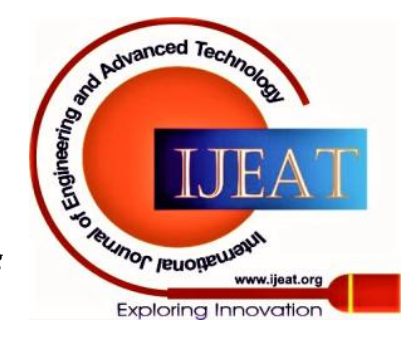




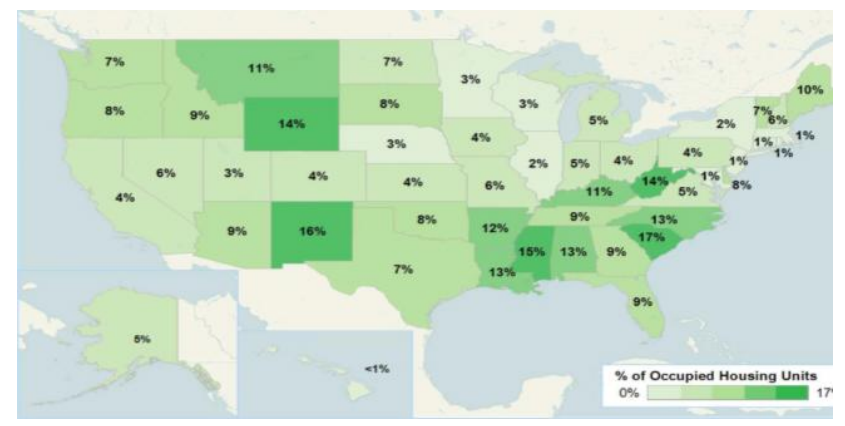

Fig. 3. Percentage of manufactured housing of occupied housing units (Adapted from CFPB report [21])

Hence, consumers finance these buildings with chattel/personal loans which are much more expensive than a mortgage. The US consumers' financing for manufactured homes is based on two types of loans [22]; 1) The chattel loan: which has lower costs at origination, requires more equity for principal payments and it results in higher interest rates and shorter maturities than mortgaging. 2) Manufactured house mortgage: which has lower interest rates than a chattel loan, but it would have higher interest rates than traditional construction mortgaging. It has better consumer protections, lower overall costs, and longer maturities. The seven steps for financing modular construction introduced by M\&T bank are a good example for manufactured house mortgage [23]. These steps include the creation of a draw disbursement schedule comprising five draws which are disbursed as planned construction milestones are completed. These five draws for construction loan are disbursed for: 1) completion of foundation; 2) delivery of modules onsite; 3) completion of house set; 4) completion of interior /exterior button up and siding; 5) completion of construction. Then, construction loan rollovers to a permanent mortgage when construction is completed. Another innovative financing option is introduced by DIRTT solutions in USA and Canada to lease manufactured homes as leasing cars, where user pays for depreciation of the product during leasing period [19]. This financial model depends on responsibility of producers/providers for their prefabricated products to be maintained and updated for new leaser after leasing term is expired. While the leaser sets leasing terms with leasing agent as shown in Figure 4. Manufactured homes in Japan are financed using mortgages which are based on recourse loan contract system [22]. This system is less risky for banks than nonrecourse loan system because if borrowers cannot pay for mortgage, they must give up any asset to pay for the loan outstanding, while USA is having a non-recourse loan system in some states, hence borrowers my default on mortgage payments and retain their other assets. In Australia, banks are conservative in financing manufactured homes [24] because they do not link financing payments to intermediate production stages. Hence, some builders have created other alternatives to ease financing their prefabricated homes. For example, Modscape provides a solution for financing privately the construction, then loan is transferred to consumers using their own bank when project is completed [21]. Other companies established connections with lenders within their group of companies (e.g., TR Homes and Resolve Finance) [22].

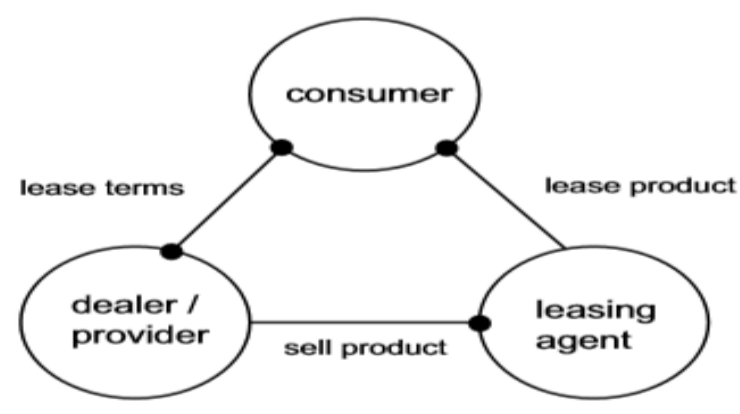

Fig. 4. Relationships between providers, leasing agents, and consumers for leasing manufactured housing. (Adapted from Smith [19]).

\section{RECENT ADVANCEMENTS}

The status of three companies named ZETA factory, Factory OS, and Katerra who worked around the bay area in California illustrate recent developments of modular and offsite construction in USA. The bay area can benefit from offsite and modular construction due to homelessness issues and high prices of real estates in its cities like San Francisco. ZETA factory in Sacramento went out of business in 2016 due to lack of capital after working for 8 years in the market due to issues with ZETA's procurement and ability to deliver projects on schedule [15]. Procurement of materials requires a large upfront capital investment before manufacturing to deliver modules on time. This is challenging for manufacturers, developers and financial partners because each stakeholder has different motivations and constraints. ZETA factory accepted most of its payments after modules are delivered and installed onsite according to the schedule and process of traditional construction. Insufficient capital of ZETA factory led to inability to pay their suppliers in a timely manner and inability to hire personnel for pre-construction activities of the next job. Another developer outlined that many lenders of ZETA factory refused to finance their project, and the lender who agreed at the end needed extensive negotiations and many exceptions to standard bank policies [9]. Hence, the main reasons behind bankruptcy of ZETA factory are the challenges of cash flow management and lack of timely capital [9]. Factory OS and Katerra present a new model of integrated start-ups that develops, designs and builds panelized and modular construction in North America. Both start-ups learned from bankruptcy of ZETA factory and they introduced a new trend in which developers own offsite construction as a result of the recent changes in the market of housing, and both start-ups are supported by venture capital investments from the IT industry in Silicon Valley to solve the homeless problem [2]. Factory OS in Vallejo, California started production in 2018 for a deal required by Google's parent company, Alphabet, to construct 300 apartments with a total value between $\$ 25$ million and \$30 million [25]. Autodesk and Citi bank are also supporting factory floor learning centre at Factory OS which is dedicated to research and education for industrialized construction.

Published By:

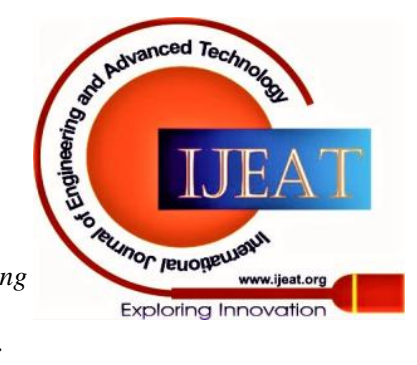

Blue Eyes Intelligence Engineering and Sciences Publication (C) Copvriaht: All riahts reserved. 
This centre is led by Terner centre for housing innovation at UC Berkeley to establish a plan for a new rapid response factory using the best automations to meet demand of quick housing after natural emergencies and disasters. Autodesk is providing software collaboration for design, fabrication and supply chain management, while Citi bank is supporting Factory OS using the initiative of spread products investment technologies (SPRINT) to finance community development projects and affordable housing [26]. Katerra was established in 2015 and built its first manufacturing facility in Phoenix, Arizona after receiving more than $\$ 1$ billion from the Japanese SoftBank as its major investor, along with other investors such as Foxconn and DFJ, while executives from Amazon and Google joined Katerra's leadership [27].

However, some issues regarding project cost overruns and delayed schedules were reported [27 \& 28]. In 2019 Katerra shut down its first factory in Phoenix and laid off 200 workers while some executives were replaced. Then another highly automated manufacturing facility was built in Tracy, California as a second-generation factory for Katerra. The business models of Factory OS and Katerra as developers and builders follow the business models of Lindbacks in Sweden and Sekisui Heim in Japan who were managing market volatility using their business model for the past 4 decades [2]. Katerra utilized their equipment in Phoenix factory from Sweden's Randek which is nearly identical to the ones used by Lindbacks in Sweden [2] while focusing more on fabrication of panelized construction and Factory OS was focused on volumetric modular construction. Australia's Lend Lease Company is also following the same trend of integrated supply chain to develop, design, and build for multifamily midrise buildings using wood cross-laminated timber (CLT). However, its operations were under review to come up with a new sustainable business model [29].

Banks are not usually risk-takers and lenders do not consider that offsite construction is affected by both real state and manufacturing risks. Repaying the capital investment of building a manufacturing facility and its ongoing operational expenses affects the business model for offsite construction industry and the expected rate of return. Range of investment cost is based on size of facility and implemented level of automation and it can be between $\$ 50$ million and $\$ 100$ million [16]. Cost impact on each project due to this investment can be between $5 \%$ and $15 \%$ of total offsite construction costs [16]. Partnerships and joint ventures are needed with municipalities, general contractors, and IT industry to validate this business model and to reduce any associated risks as well as increasing financing schemes for owners and developers of modular and offsite construction. In USA, Federal and state funding schemes are introduced to support collaboration between industry and universities to enhance construction productivity for modular and offsite construction [2]. The modular building institute (MBI) is developing a procurement guide for general contractors and modular builders by engaging members of the associated general contractors of America (AGC) to help project teams navigating through lending, bonding, insurance, permitting,

\section{FUTURE OPPORTUNITIES}

and inspection for modular and offsite construction which are different from traditional construction [2]. MBI is also working with an organization named; the housing crisis solutions coalition (HCSC) which believes that federal affordable housing policies, such as low-income housing tax credit (LIHTC) are not efficient. HCSC believes that modular and offsite construction can develop affordable housing quickly to be occupied earlier by low-income renters to avoid the need for tax credits. However, some states can offer developers' tax credits as the one presented by State of Virginia for innovative construction processes that develop housing inventory quickly. [1] A recent action plan was also suggested to the state of Minnesota by industry leaders from around the state to make $10 \%$ of multi-family residential developments use offsite construction in Minnesota by 2025 using five steps: 1) Starting multi-sector innovation cohorts to explore challenges and potential of using offsite construction. 2) Promoting learning opportunities to educate lenders, general contractors, and architects about benefits and characteristics of modular and offsite construction. 3) Enhancing local collaboration to fast-track pre-approvals for offsite construction projects. 4) Incentivizing pilot projects using public-private partnership (PPP) which utilize modular and offsite construction. 5) Attracting new modular builders and investors to Minnesota by an economic development campaign [32]. In Australia, the federal government is supporting the advanced manufacturing growth Centre which is a non-profit advocacy group established in 2015- to issue grants for business development. This centre supports manufacturing companies to increase their capabilities, scope, and scale [2]. In the UK, The Housing Corporation, which is the non-departmental public organization that funds new affordable housing - started in 2004 to require that 25\% of new social housing being funded by the organization should utilize offsite construction. However, the influence of governments on private sector was limited, and they did not provide direct incentives through building regulations or planning policies [30]. Hence, the housing, communities and local government committee presented a white paper to the parliament in 2017 that recognizes the importance of embracing offsite construction to meet UK's plan for building 300,000 homes a year by the mid2020s [33]. The government response to this white paper was introduced in 2019 outlining many steps to address this issue including their support to financing offsite construction using $£ 236 \mathrm{~m}$ from the home building fund to support to projects that incorporate offsite construction [34]. As well as establishing an offsite construction working group to address barriers to financing and insurance of offsite construction.

\section{CONCLUSIONS}

This paper presented a literature review for the challenges associated with financing modular and offsite construction, and the current trends in financial modelling from the developer perspective and in mortgage financing for

\section{Published By:}

Blue Eyes Intelligence Engineering and Sciences Publication

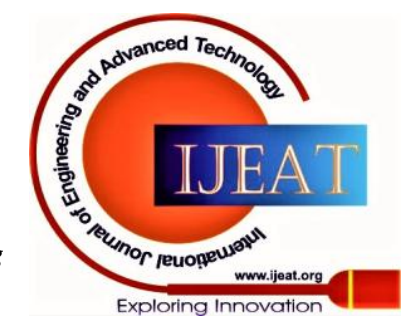


consumers. Recent advancements in financing modular and offsite construction were also introduced relevant to the new practices of partnering with unconventional financing sources such as venture capitals and IT companies, as well as the cash flow problems incurred by developers. The future opportunities in USA, UK, and Australia were also discussed to present different initiatives developed by organizations and governments to support the use of modular and offsite construction. It is concluded that a steady demand and support for modular and offsite construction projects could reduce any risks associated with the manufacturing and construction of this industry. Modular and offsite construction projects need to explore new sources of funding and need to develop new sustainable business and financial models.

\section{REFERENCES}

1. Modular Building Institute (MBI). The U.S. Construction Industry: A National Crisis Looming, Modular Building Institute. On-line: https://www.modular.org/documents/document_publication/national-cr isis-looming-whitepaper.pdf, 2019.

2. Smith R., Rupnik I. 5 IN 5 Modular growth initiative research roadmap recommendations, Modular Building Institute.

https://www.modular.org/documents/document_publication/2018_101 9\%205in5\%20Deliverable.pdf, 2018.

3. Rahman M.M. Barriers of implementing modern methods of construction. Journal of management in engineering, 30(1), pp.69-77, On-line: https://doi.org/10.1061/(ASCE)ME.1943-5479.0000173, 2014.

4. Smith R. E. and Rice T. Permanent modular construction; process, practice, performance. Special report from Modular Building Institute. 48 pages, 2015.

5. Canadian construction innovations (ccinnovations). Challenges and opportunities for modular construction in Canada, Workshop Summary Report hosted jointly by Concordia University, the Modular Building Institute, Canadian Construction Innovations, and the University of Alberta, 21 pages, 2015.

6. Salama T, Moselhi O, Al-Hussein M. Modular Industry Characteristics and Barriers to its Increased Market Share. Modular and Offsite Construction (MOC) Summit Proceedings. 1(1), On-line: https://doi.org/10.29173/mocs34, 2018.

7. Salama T, Moselhi O, Al-Hussein M. Modular Industry Characteristics and Barriers to its Increased Market Share. Special report published at the website of Modular Building institute. Online: https://www.modular.org/documents/document_publication/Modular_I ndustry_Characteristics_and_Barrier_to_its_Increased_Market_Share. pdf , 2018

8. Salama, T. Optimized planning and scheduling for modular and offsite construction. PhD thesis, department of building, civil and environmental engineering, Concordia University, Canada, 2019.

9. Galante C, Draper-Zivetz S, Stein A. Building Affordability by Building Affordably: Exploring the Benefits, Barriers, and Breakthroughs Needed to Scale Off-Site Multifamily Construction. Terner Centre for http://ternercenter.berkeley.edu/uploads/offsite_construction.pdf 2017.

10. Maher A. Breaking with tradition. Special report from AVANA capital. https://avanacapital.com/wpcontent/uploads/Expert-Speak-FinanceHT _MARCH_ISSUE_-2018.pdf , 2018.

11. Cameron P. J., Carlo N. G. D. Piecing together modular: understanding the benefits and limitations of modular construction methods for multifamily development. Master of Science thesis in real estate development, Dept. of Architecture, Massachusetts Institute of Technology, On-line: http://hdl.handle.net/1721.1/42038 , 2007.

12. Feutz D. The Hurdles to Financing Modular Development. Cornell Real Estate Review, 17(1), p.23, 2019.

13. Velamati, S. Feasibility, benefits and challenges of modular construction in high rise development in the United States: a developer's perspective, Master of Science thesis in real estate development, Dept. of Architecture, Massachusetts Institute of Technology, On-line: http://hdl.handle.net/1721.1/77129 , 2012.

14. Steinhardt D., Manley K. Exploring the beliefs of Australian prefabricated house builders. Construction Economics and Building. Housing Innovation, UC Berkeley. Online:

16(2):27-41, On-line: https://doi.org/10.5130/AJCEB.v16i2.4741, 2016.

15. Stein A. Disruptive Development: Modular Manufacturing in Multifamily Housing. Master of city planning thesis, department of city and regional planning, University of California, Berkeley. 2016.

16. Bertram N., Fuchs S., Mischke J., Palter R., Strube G. and Woetzel J. Modular construction: From projects to products. McKinsey \& Company: Capital Projects \& Infrastructure, pp.1-34, 2019.

17. Abu-Khalaf A. Overcoming barriers to bringing off-site construction to scale. Special report by Enterprise Community Partners and funded by JPMorgan Chase Foundation, On-line: https://www.enterprisecommunity.org/download?fid=11694\&nid=884 $\underline{5}, 2019$.

18. American Institute of Architects (AIA). Design for modular construction: an introduction for architects, Special report by AIA, On-line: http://content.aia.org/sites/default/files/201903/Materials_Practice_Guide_Modular_Constructi on.pdf , 2019.

19. Smith, R. E. Prefab architecture: a guide to modular design and construction, Wiley Publications, ISBN: 978-0-470-27561-0, 400 pages, 2010.

20. Cazemier D. Comparing cross laminated timber with concrete and steel: a financial analysis of two buildings in Australia. Modular and Offsite Construction (MOC) Summit Proceedings, 2017.

21. Consumer Financial Protection Bureau CFPB. Manufactured-housing consumer finance in the United States, On-line: https://files.consumerfinance.gov/f/201409 cfpb report manufactured -housing.pdf , 2014.

22. De Mendoza C. Prefabrication: a solution for a NZ housing shortage? Special report by PrefabNZ, Online http://www.prefabnz.com/Downloads/Assets/Download/9728/1/Prefab NZ\%20CnC\%20Lit\%20Review\%20FINAL\%20180302.pdf , 2018.

23. M\&T bank. Understanding modular home construction financing: a customer guide, On-line: https://asset.mtb.com/Documents/pdf/modularhome-construction-finan cing.pdf , 2018.

24. Boyd N., Khalfan M. \& Maqsood T. Off-Site construction of apartment buildings. Journal of Architectural Engineering, 19, 51-57, On-line: https://doi.org/10.1061/(ASCE)AE.1943- 5568.0000091, 2012.

25. Kusisto L. Google will buy modular homes to address housing crunch. The wall street journal, On-line: https://www.wsj.com/articles/google-betson-modular-homes-to-fill-hou sing-demand1497448838, 2017.

26. Anagnost A. Autodesk invests in Factory OS to advance modular construction, On-line: https://adsknews.autodesk.com/news/autodeskinvests-in-factory_os-tomake-affordable-housinga-reality, 2019.

27. Brenzel K. and Jeans D. Warped lumber, failed projects: TRD investigates Katerra, SoftBank's \$4B construction startup, The Real Deal: New York real estate news, On-line: https://therealdeal.com/2019/12/16/softbankfunded-construction-startu p-katerra-promised-atech-revolution-its-struggling-to-deliver/ , 2019.

28. Dodge data and analytics. Prefabrication and modular construction 2020: smart market report, Special report by Dodge data and analytics, On-line: $\quad$ https://www.modular.org/documents/public/Pr efabModularSmartMarketReport2020.pdf , 2020.

29. Perinotto T. Future of Lendlease's DesignMake is under review, the fifth estate, On-line: https://www.thefifthestate.com.au/business/inves ment-deals/future-of-lendleases-designmake-isunder-review/ , 2019.

30. Pan W, Gibb AG, Dainty AR. Leading UK housebuilders' utilization of offsite construction methods. Building research \& information. 1; 36(1):56-67, On-line: https://doi.org/10.1080/09613210701204013, 2008.

31. Elnaas E. The decision to use off-site manufacturing (OSM) systems for house building projects in the $\mathrm{UK}, \mathrm{PhD}$ thesis, University of Brighton, 2014.

32. Construction revolution summit. A cross- sector collaboration to reduce the cost of housing by creating an innovation hub for offsite construction, Summit report and action plan for Minnesota, Online: https://static1.squarespace.com/static/5d4b4a44a49c3800010ab89d/t/5 edfe7dd5875a7412de91285/1591732195568/Construction_Revolution Action_Plan.pdf, 2020.

33. Department for communities and local government. Fixing our broken housing market. Special report presented to parliament, On-line:

Published By:

Blue Eyes Intelligence Engineering

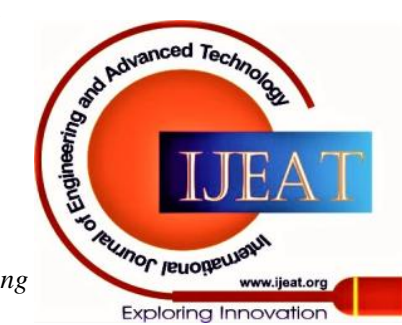


https://assets.publishing.service.gov.uk/government/uploads/system/up loads/attachment_data/file/590464/Fixing_our_broken housing_marke t _ _ print_ready_version.pdf, 2017.

34. Ministry of housing, communities and local government. Government response to the housing, communities and local government select committee report on modern methods of construction, Special report presented to parliament, On-line: https://assets.publishing.service.gov.uk/government/uploads/system/up loads/attachment_data/file/832176/SC_168___modern_methods_of_co nstruction.pdf , 2019.

\section{AUTHORS PROFILE}

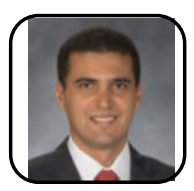

Tarek Salama is an Assistant Professor at the construction management department, California state university, Sacramento. From 2003 to 2012, Dr. Salama worked in several multinational organizations relevant to offshore, onshore and oil and gas industries. His research interests include structural analysis, modular construction, project planning and scheduling. Dr. Salama is an associate member at the American Society of Civil Engineers (ASCE), a member of the associated schools of construction (ASC) and the Egyptian Engineers Syndicate and holds a project management professional certificate (PMP) from the project management institute (PMI). He received Hydro Quebec financial award from the faculty of engineering and computer science in Concordia University from 2014 to 2016, and the Stephen G. Revay Award from the Canadian Society for Civil Engineering (CSCE) in 2018. Also, he is reviewer of international top-tier scholarly journals.

Website: www.linkedin.com/in/tarek-salama-ph-d-pmp-b2366a17/

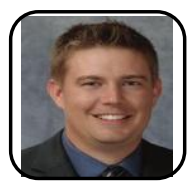

Gareth Figgess is an Associate Professor at the construction management department, California state university, Sacramento. He teaches a range of courses including construction surveying and layout, soils and foundations, and construction graphics and visualization. Professor Figgess' professional background is predominantly infrastructure and heavy-civil related, but since joining the faculty at CSU Sacramento in 2013, he has pursued several research opportunities in sustainability and net-zero energy building design. Professor Figgess was the lead faculty advisor for the CSU Sacramento entry into the US Department of Energy Solar Decathlon 2015 and played a supporting role in the 2016 SMUD Tiny House Competition. Figgess holds a BS in Construction Management and an MBA. His research interests includes stainability, water conservation, and renewable energy, as well as methods of teaching and learning.

Website: www.linkedin.com/in/gareth-figgess-6815331a/

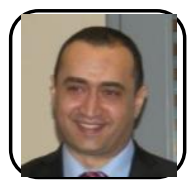

Mohamed Elsharawy is an Assistant Professor at Structural Engineering Department, Mansoura University, Mansoura, Egypt. He received his Ph.D. in Civil (Structural) Engineering from Concordia University, Montreal, Canada. His M.Sc. in Structural Engineering and B.Sc. in Civil Engineering degrees from Mansoura University, Mansoura, Egypt. His research interests include Wind Effects on Structures, Vibration Mitigation, Seismic Assessment and Retrofit of Existing Structures, Modular Construction and Codification of Wind and Seismic Effects on Structures.

Website: www.researchgate.net/profile/Mohamed_Elsharawy4

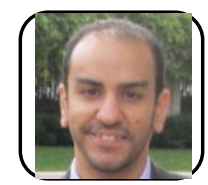

Hossam El-Sokkary is an Assistant Professor in the Structural Engineering Department, Ain Shams University, Cairo, Egypt. He received the M.Sc. and Ph.D. degrees in Civil (Structural) Engineering from Concordia University, Montreal, Canada, and the B.Sc. degree in Civil Engineering from Ain Shams University. His research interests include Seismic Assessment and Retrofit of Existing Structures, Structural Dynamics and Earthquake engineering, Modular Construction and Numerical Modeling of Structures.

Website: https://eng.asu.edu.eg/staff/elsokkary.hossam

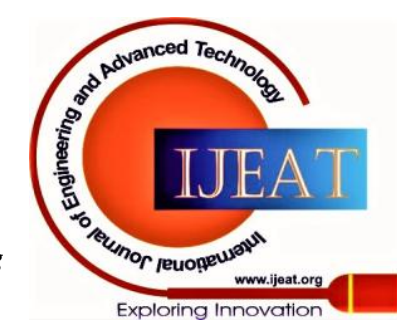

